\title{
EXPERIENCES OF THE MENTORING RELATIONSHIP: A STUDY IN A MINING COMPANY
}

\author{
NELISE GILMORE \\ MELINDE COETZEE \\ DRIES SCHREUDER \\ Department of Industrial and Organisational Psychology \\ College of Economic and Management Sciences \\ University of South Africa
}

\begin{abstract}
The purpose of this study was to investigate the experiences of mentors and mentees with regard to the mentoring relationship in the South African organisational context. A convenience sampling method was used to involve mentors and mentees as participants $(\mathrm{N}=10)$. Qualitative methods were used to collect and analyse data on the respondents' experiences of the mentoring relationship. It was found that both mentors and mentees tend to prefer informal mentoring relationships because of the factors that contribute to the quality of the relationship. The implications of the findings are discussed.
\end{abstract}

\section{OPSOMMING}

Die doel met hierdie studie was om die aard van die ervaringe van mentors en mentees aangaande die mentorverhouding in die Suid-Afrikaanse organisatoriese konteks te ondersoek. Gerieflikheidsteekproefneming is aangewend om mentors en mentees $(\mathrm{N}=10)$ as navorsingdeelnemers te betrek. Kwalitatiewe metodes is benut om data omtrent die respondente se ervaring van die mentorverhouding te versamel en te ontleed. Daar is bevind dat beide mentors en mentees neig om die informele mentorverhouding te verkies weens die faktore wat die gehalte van die verhouding verhoog. Die implikasies van die bevindinge word bespreek.

Political, economic, technological and cultural changes are having a profound impact on the world of work and are bringing new challenges to the management of people in the workplace, particularly the planning and managing of careers. Organisations worldwide are increasingly staffed by diverse groups of employees (Aryee \& Debrah, 1993; Baruch, 1999; 2002; 2004; Furnham, 2000; Greenhaus, Callanan \& Godshalk, 2001). In the South African context, historically disadvantaged South Africans (Africans, Coloureds, Indians and women) are climbing the corporate ladder and it is clear that only effective management of the diverse workforce will ensure a competitive edge (Grobler, Warnich, Carrell, Elbert \& Hatfield, 2002).

Mentoring is a valuable resource for individual and organisational learning, and for coping with an unstable and dynamically changing workplace (Kram \& Hall, 1996; Siegel \& Reinstein, 2001). To cope effectively with change requires a different process of learning - one that mentoring can provide. Kram and Hall (1989) assert that mentoring helps to ease stress during times of "corporate trauma" when an organisation is downsizing, for example. Mentoring can also be used to help employees to take ownership of their careers and thereby navigate their careers successfully (Baruch, 1999; Hay, 1995). According to Clutterbuck and Sweeney (2003), very few people now have linear career paths - that is, where it is possible to see several steps ahead. The reality for most people is that they need to both maximise the potential for learning in the job they have now, and constantly be alive to opportunities to gradually move into new roles. Managing both the major and the minor transitions becomes a lot easier when one has a dispassionate but well-disposed mentor, who can take a broader view and help one to think through the options and implications of each opportunity.

A mentor is often described as a senior, experienced employee who serves as a role model, and who provides support, direction and feedback to the younger employee in terms of career plans and interpersonal development (Baruch, 1999: 441; Finkelstein, Allen \& Rhoton, 2003:249; Noe, 1988:458). Although older mentors paired with younger mentees may still be the norm, changes encompassing today's workplace, such as multiple lifetime career paths and a protean approach to career

Requests for copies should be addressed to: M Coetzee, coetzm1@unisa.ac.za development (Baruch, 2004; Hall \& Mirvis, 1995), will likely increase the occurrence of similar-age (that is, peer mentoring) and reverse-age (that is, mentor younger than mentee) mentorships (Allen, McManus \& Russell, 1999; Finkelstein et al., 2003; Klasen \& Clutterbuck, 2002; Kram, 1996). Mentoring appears to work best when the need is the acquisition of wisdom. Clutterbuck and Sweeney (2003) refer to wisdom as the ability to relate what has been learnt to a wide spectrum of situations, and to achieve insight into and understanding of the issues discussed. In this regard, mentoring is regarded as one person's off-line help of another towards making significant transitions in knowledge, work or thinking (Clutterbuck, 2001).

The mentor is a person who has greater experience than the mentee, but may not necessarily be superior in status. The mentor acts in a nondirective manner, helping the mentee develop his or her own wisdom, rather than imposing his or her own. The relationship is primarily mentee-driven as the aim of the relationship is to develop the mentee's self-reliance and remove the need for a mentor. The benefits of mentoring for the mentee can include faster career progress, increased confidence, assistance with working through difficult issues when dealing with other people, having a sounding board to try out ideas, and being able to draw on someone else's experience. Mentoring opens the mentee up to new issues and adds layers of thinking by developing new insights. In the organisational context, this may mean demonstrating appropriate patterns of thinking (through behaviour or understanding, or both) which usually convinces superiors that the individual is ready and able to take on new and/or larger tasks (Clutterbuck, 2001; Clutterbuck \& Sweeney, 2003; Schuitema, 1998). The organisation benefits in terms of increased staff retention, especially among new recruits, when a mentor helps them fit in more easily and rapidly. Other benefits include passing on best practice, raising the quantity and quality of self-managed learning, and generally reinforcing a development culture (Baruch, 1999; Clutterbuck \& Sweeney, 2003; Daloz, 1999; Hay, 1995; Klasen \& Clutterbuck, 2002).

For the mentee, negative features arise mostly from poor selection or training of mentors (Klasen \& Clutterbuck, 2002). Identification is a key process that guides the mentor's selection of the mentee, and vice versa. For mentors, the 
development of the relationship serves an intrinsic development need that is guided, in part, by their identification with the mentee (Clutterbuck \& Ragins, 2002). Research indicates that mentors choose mentees who are viewed as being similar to themselves (Allen, Poteet \& Burroughs, 1997) and that satisfaction with the relationship increases with perceived similarity (Ensher \& Murphy, 1997). To the extent that mentees select mentors, identification may also guide the mentee's selection of the mentor. Mentees may choose mentors who are viewed as competent role models; the mentor represents what the mentee wants to become (Clutterbuck \& Ragins, 2002; Ragins, 2002).

\section{Diversity in mentoring relationships}

Although mutual identification guides the development of mentoring relationships, development of diversified relationships is affected by the availability and sheer number of mentors from a specific race or gender group. In most South African organisations, the higher the rank the fewer the number of women and Africans, Coloureds and Indians. White males are still predominantly occupying higher positions and are also the more experienced in terms of the various race and gender groups. Legislation on employment equity and skills development requires that mentoring practices are based on the formation of cross-cultural and cross-gender mentoring relationships in the South African organisational context.

Given the mutual identification processes underlying the development of mentoring relationships, diverse mentoring relationships clearly pose many challenges to both mentors and mentees (Clutterbuck \& Ragins, 2002; Linehan \& Walsh, 1999). However, identification may still occur in diverse relationships, although this identification may be based on similarities in values, backgrounds, personalities and interests. According to Ragins (2002), perceived diversity in mentoring relationships is affected by differences based on group memberships, as well as deeper, individually based differences. Individual diversity is influenced by group diversity since the values, beliefs and attitudes of mentors and mentees are affected by their group memberships. While mentors and mentees may objectively differ on group membership or individual characteristics, these differences may or may not be viewed as important by the members of the relationship (Ragins, 2002; Ragins \& McFarlin, 1990). Mentors and mentees in diverse relationships may find they have much in common, but this discovery takes time and a deeper level of interaction. Mentoring relationships that are homogeneous may thus be easier to initiate than those that are diverse (Clutterbuck \& Ragins, 2002; Finkelstein et al., 2003; Klasen \& Clutterbuck, 2002).

Mentors and mentees may initially connect on the basis of perceived similarities or group diversity, but over time may find other even more important, individual similarities that help create a successful mentoring relationship. Proper training, support, communication and patience may help optimise the diversity in the relationship while the mentor and mentee are finding common ground in terms of values, interests, hobbies, families or background. However, the opposite may also be true: mentors and mentees may develop relationships based on similarity of group membership, but with time they may find that they have little else in common (Ragins, 2002). This has important implications for mentoring programmes. Programmes that pair mentors and mentees solely on the basis of gender or race may find that members connect on the basis of these group memberships and the important experiences associated with being historically disadvantaged or being a woman in the organisation and the society, but they may or may not connect on other, deeper levels of diversity that define their inner values and sense of self (Athey, Avery \& Zemsky, 2000; Ragins, 2002).
Organisational context plays a key role in saliency perceptions. Race differences in a mentoring relationship may be less salient to the members of the relationship when they work within groups or organisations that are racially and ethnically diverse, compared with those who work in homogeneous settings (Athey et al., 2000). Against this background, it appears that saliency of differences and social identity of members moderate the relationship between objective and perceived differences. According to the Social Identity Theory (Ashforth \& Mael, 1989; Tajfel \& Turner, 1986), individuals classify themselves according to social categories that shape their identities and allow them to define themselves in relation to their social environment. Mentors and mentees have multiple social identities, and some identities may be more important than others in developing a sense of self and establishing the common basis for the mentoring relationship (Ragins, 2002). Informal mentoring relationships may develop naturally on the basis of shared social identities and group memberships, but formal relationships are typically matched by third parties (Ragins, Cotton \& Miller, 2000). A mentoring programme coordinator does not automatically know which social identities are salient and important to the members of the relationship and may, therefore, match members based on his or her perceptions of shared group membership, rather than the perceptions of the members of the relationship. It may thus be advisable to ask members of the formal relationship about their social identities, needs and preferences before making the match (Ragins, 2002).

\section{Formal and informal mentoring relationships}

The nature of a mentoring relationship is influenced by the degree of formality espoused by the mentoring programme which, in turn, influences the degree of formality present in a mentoring relationship. The degree of formality present in the mentoring relationship appears to influence the dynamics and outcomes of the relationship (Fagenson-Eland, Marks \& Amendola, 1997; Ragins \& Cotton, 1999). Formal mentoring programmes and relationships are planned, implemented and managed by the organisation in a highly structured manner, involving various control mechanisms. This contrasts with a very informal mentoring programme, and equally informal mentoring relationships which develop spontaneously (Klasen \& Clutterbuck, 2002).

Research by Chao, Walz and Gardner (1992), Kram (1983) and Ragins and Cotton (1999) indicate that informal mentoring appears to engender more satisfied mentees who perceive their mentors as more effective and more motivated, with better communication and coaching skills. Frequent, open and honest discussion seems to help create a trusting, encouraging and open atmosphere that helps release the mentee's potential and motivation. The nature of the mentoring relationship resembles that of a professional friendship. It is a voluntary relationship in which the mentor functions as the trusted friend who listens, guides and enables through skilful questioning and, if appropriate, making direct suggestions (Chao et al., 1992; Klasen \& Clutterbuck, 2002; Kram, 1983; Ragins \& Cotton, 1999).

Informal mentoring also appears to mainly benefit the mentee (Klasen \& Clutterbuck, 2002). Formal mentoring, on the other hand, seems to promote a more equal balance between organisational and individual benefits. Table 1 summarises the perceived organisational and individual benefits of formal mentoring.

Formal mentoring programmes provide a structure that can enable individuals who might otherwise find it difficult to access influence networks to overcome tacit or explicit barriers to commencing mentoring relationships. This contrasts strongly with informal mentoring, which has a tendency to be highly selective. According to Klasen and Clutterbuck (2002), mentors tend to pick only successful individuals as mentees. Those 
mentees in greater need are then often denied an important development opportunity. This kind of self-regulation unfortunately creates perceptions of unfairness amongst employees. Clutterbuck (2001) has observed that, left to their own devices, mentees will seek mentors who are either easy for them to get on with, or high-flyers who may provide a career towrope for their mentees.

TABLE 1

ORGANISATIONAL AND INDIVIDUAL BENEFITS SOUGHT THROUGH FORMAL MENTORIN

\begin{tabular}{ll}
\hline Organisational benefits & Individual benefits \\
\hline Retention & Career development \\
$\begin{array}{l}\text { Best use of talent } \\
\text { gaining experience }\end{array}$ & Opportunities for learning and \\
Performance & Skills development \\
$\begin{array}{l}\text { Knowledge sharing } \\
\begin{array}{l}\text { Safety valve for key staff to work } \\
\text { through concerns }\end{array}\end{array}$ & $\begin{array}{l}\text { Having a sounding board and/or } \\
\text { counsellorto promote career moves }\end{array}$ \\
\hline
\end{tabular}

(Klasen \& Clutterbuck, 2002:128)

Obviously mentoring associations will vary as to the degree of satisfaction experienced by mentor and mentee. At one extreme, there might be dissatisfying or even dysfunctional relationships, while at the other extreme there might be highly satisfied pairs. Ragins and Cotton (2000) find that satisfaction with the mentoring relationship has a stronger impact on career attitudes such as career commitment, job satisfaction, organisational commitment and intention to quit than the issue whether the mentoring was formal or informal. Studies by Kogler-Hill and Bahniuk (1998) also suggest that there are no differences between the formal and informal mentoring relationship in terms of the fulfilment of psychosocial functions. However, overall, informal mentoring appears to fulfil greater career functions than formal mentoring.

Research and literature within the South African diverse context regarding mentors' and mentees' experiences of the mentoring relationship seem to be limited. This study is motivated by the lack of knowledge and understanding about the factors that contribute to the quality of the mentoring relationship in the South African organisational context. The purpose of this study is therefore to gain an in-depth understanding about mentors' and mentees' subjective experiences of the mentoring relationship. More specifically, the aim was to answer the following research questions:

- What are mentors' and mentees' subjective experiences of the mentoring relationship?

- What are the key factors which contribute to the quality of the mentoring relationship?

\section{RESEARCH DESIGN}

\section{Research approach}

Merriam (2002) recommends that a qualitative approach be used when the research objectives are exploratory and descriptive. Qualitative researchers assert that the social world can only be understood if its social context is taken into consideration (Bogdan \& Biklen, 1998). The main objective of qualitative research is therefore to understand the dynamics of human meaning in its natural setting, with minimal interference from the researcher. Since the research questions pertain to understanding and describing a particular phenomenon about which very little is known, the qualitative approach seems the most suitable for gaining insight about participants' subjective experiences of the mentoring relationship in their work setting. Qualitative research enables a researcher to understand the participants' experience when trying to understand situations from a particular perspective (Creswell, 1994).

This study was therefore conducted within a qualitative paradigm and the grounded theory method was used to develop an inductively derived theory (Strauss \& Corbin, 1990). This method enabled the researcher to study the phenomenon of the mentoring relationship within its context and facilitated the systematic generation of theory from, and grounded in, the data regarding the factors that contribute to the quality of the mentoring relationship.

\section{Respondents}

The study was conducted at a large mining company in North West province. A convenience sample (Huysamen, 1994) comprising four mentors and six mentees $(\mathrm{N}=10)$ were approached for the present study. The sample included four white male mentors, three white male mentees and three African female mentees. Of the four mentors, two were involved in an informal mentoring relationship and two were involved in a formal mentoring relationship. Four of the six mentees were involved in an informal mentoring relationship, while two mentees were involved in a formal mentoring relationship. Selection of the respondents was based on their participation in the company mentoring programme within the last year. Qualitative methodologies attempt to access a richness of diverse information from a few participants and frequently regard participant sizes of less than 10 to be sufficient (Schurink, 2003).

A brief background of the company mentoring programme The mining company has a mentoring programme in place that is open to all employees. This is applicable to informal and formal mentoring relationships. The purpose of the company mentoring programme is to provide guidance in respect of the company's approach to its people development process, to facilitate the development or accelerated development of the company's young professionals and the Employment Equity Talent Pool, as well as to guide the implementation of mentoring as a Human Resource Development (HRD) system.

Informal mentoring relationships may come about through the mentee assessing a personal need for mentoring or through a friendship that has evolved into a mentoring relationship. Provision has been made for a company register of trained mentors in order to provide access for all employees (who feel the need for an informal mentorship relationship) to trained mentors. According to company policy, mentoring is voluntary. Both the mentees and mentors reserve the right to accept or decline the opportunity presented to participate in the mentoring relationship, whether informal or formal. Provision is made for numerous mentoring relationships involving multiple mentors or mentees at a time. However, a guideline mentee ratio of not more than 5:1 is recommended.

It is stipulated that participants in the programme will participate in mentoring training and that records of all mentoring sessions be kept for auditing purposes. The supporting documentation stipulates guidelines on criteria for mentoring, the roles and responsibilities of the mentors, the identification of mentees for the mentoring system, the identification of developmental needs, mentorship training, how to choose a mentor/mentee, the mentoring relationships, the training needs analysis identified within the mentoring relationship, the updating of information systems to keep records and the continuous monitoring of the relationship. A procedural document prescribes the detail required to implement the policy document. The programme is formalised through agreements signed by both parties (mentee and mentor). 


\section{Methods of data gathering}

The study was conducted within a qualitative paradigm (Huysamen, 1994). The qualitative data collection technique in this study included semi-structured face-to-face interviews. The interviews were structured around the two research questions. All interviews were ended with an open question allowing for respondents to share any information or experience they felt relevant that had not been explored or discussed during the interview.

The following two open-ended questions were carefully formulated and put to the respondents:

- How do you experience your mentoring relationship?

- What are the key factors which contribute to the quality of your mentoring relationship?

\section{Procedure}

Firstly, permission was obtained from the Human Resource Manager of the company where the interviews were conducted. Thereafter the researcher contacted the mentors and mentees telephonically to establish their availability and willingness to participate in the research study. The respondents were briefed on the reason and format of the interview by means of a short introduction. They were given the opportunity to withdraw from participation in the study. Interview appointments were then arranged with each respondent.

\section{Data analysis}

Based on the suggestions of Strauss and Corbin (1990) and Creswell (1994), data analysis was conducted systematically whereby the researcher keeps track of emerging themes during the data gathering process, and develops concepts and propositions to make sense of the data. Underlying themes were deduced followed by a coding process, during which sections of the data collected were labelled as being of relevance to one or more of the identified themes. The themes that emerged were interpreted in light of existing literature on the topic, enabling meaningful interpretation of the results.

\section{RESULTS}

Overall, mentoring was regarded as a valuable experience for both mentors and mentees. However, the main findings indicated that both mentors and mentees found the informal mentoring relationship more positive than the formal mentoring relationship. As suggested by Strauss and Corbin (1990) and Cresswell (1994), several themes relating to the phenomenon of a mentoring relationship emerged from the data analysis. In the next section these themes will be discussed. From the themes it was possible to develop responses to the research questions.

\section{Experiences of the mentoring relationship}

The body language of the respondents and the tone of the interviews were generally positive and encouraging. Mentees involved in informal mentoring relationships perceived the relationship as "worth it", whereas the mentees involved in formal mentoring relationships did not perceive the relationships as satisfying. Although the mentors perceived the mentoring relationship as valuable, it was indicated that they preferred the informal to the formal mentoring relationship. One of the mentors summed it up: "I have never liked the formal mentee-mentor relationship, although experience has proved to me that there is little difference. At the end of the day, mentoring is the most important, whether done formally or informally."

The mentee respondents viewed the potential benefits of the mentoring relationship as that of increasing their technical and behavioural competence, facilitating the achievement of their career goals, having a wider network of influence or learning resources, and increasing their confidence. The mentoring relationship was also viewed as a mechanism to facilitate promotional opportunities within the company.

Negative experiences regarding the mentoring relationship evolved around communication and the perceived commitment of the mentor. It was evident that the nature of communication between the mentors and mentees involved in the informal mentoring relationships was more positively experienced than was apparent in the formal mentoring relationships. Mentors in the informal mentoring relationship were perceived to be more committed than those involved in formal mentoring relationships.

\section{Factors influencing the quality of the mentoring relationship}

Overall the mentee respondents who were engaged in an informal mentoring relationship said they were satisfied with the mentoring relationship because they had been allowed to choose their own mentors. Mentors were chosen on the basis of sharing a similar value system with the mentee. Respect for the mentor's success in the company was also viewed as a factor that contributed to the perceived quality of the relationship. Although all the mentees had only white male mentors, none of the respondents reported challenges regarding cross-gender or cross-cultural relationships.

Mentor-mentee commitment and communication were regarded as ways to improve both the informal and formal mentoring relationship. The perceived commitment of the mentors was attributed to mentor characteristics such as showing interest in the mentees' career progress, mentoring expertise and status of the mentor, sharing similar values, giving direction and structure to the mentoring relationship, a positive attitude and excellent communication skills.

The respondents involved in formal mentoring relationships expressed dissatisfaction with the relationships and suggested improvements regarding interaction and frequency of communication. Respondents involved in an informal mentoring relationship appeared to communicate on a more personal level (either face-to-face or telephonically). They reported communicating as and when required rather than on a formal monthly or quarterly basis, as was apparent with the mentors and mentees involved in a formal relationship.

The mentee respondents regarded career development support in setting goals and targets as important factors that contribute to the quality of the relationship. Although the informal nature of the mentoring relationship was preferred, respondents expressed the need for a formal structure that allowed goals, objectives and targets to be met within the framework of the relationship.

None of the mentors reported that they had followed the mentoring training offered by the company and one mentor responded by saying that "mentoring relationships develop naturally and not necessarily according to rules laid down in training".

\section{DISCUSSION}

The data gathered from individuals' subjective experiences of the mentoring relationship will subsequently be discussed in terms of the aims of this study, namely to clarify how the respondents experienced the mentoring relationship and what they perceived to be the factors contributing to the quality of the mentoring relationship. To clarify the particular social makeup of the respondents, experiences and views will also be related to existing empirical findings and relevant abstract theoretical concepts.

While mentors and mentees may objectively differ on group membership or individual characteristics (as in the case of the African female mentees who were matched with the white male 
mentors), these differences were not viewed as important by the members of the relationship (Ragins, 2002; Ragins \& McFarlin, 1990). The results suggest that being allowed to choose one's own mentor based on one's personal preferences was regarded as more important and led to the perceived satisfaction with the mentoring relationship (Klasen \& Clutterbuck, 2002; Ragins, 2002). Sharing similar value systems and having respect for the mentor's success in the company appear to be important matching selection criteria when assigning mentees to mentors. This is in line with the research findings of Clutterbuck (2001) and Klasen and Clutterbuck (2002).

The findings of the study suggest that factors contributing to the emotional outcomes of the mentoring relationship also improved the perceived quality of the relationship. These included having a reflective space through frequent communication and interaction with the mentor, as well as career development support in setting goals and targets. Both formal and informal mentoring relationships appear to benefit from a formal structure that accommodates the mentees' career goals, and which includes regular reviews and formalised discussions (Clutterbuck, 2002; Megginson \& Clutterbuck, 1995).

The mentor's commitment and communication competencies were regarded as important characteristics in improving the quality of the relationship. Mentors must be volunteers, interested in the programme and effective one-on-one communicators. Furthermore, mentors must be able to foster self-reliance and selfconfidence within the mentee. They should also enable mentees to identify their development needs and goals and be able to help mentees solve problems by analysing, reflecting and enhancing their self-awareness (Clutterbuck, 2002).

Informal mentoring appears to be regarded as more valuable than the formal mentoring relationship. Research by Chao et al. (1992), Kram (1983) and Ragins and Cotton (1999) also indicates that informal mentoring appears to engender more satisfied mentees who perceive their mentors as more effective and more motivated with better communication and coaching skills. According to Clutterbuck (2001), one of the goals of a formal mentoring programme should be to bring the organisation to the point where most mentoring is carried out informally, without the need for substantial, structured support by Human Resources. However, informal mentoring relationships should still provide structure and guidance about mentor and mentee roles.

The findings of the study suggest that the success of the mentoring relationship lies within the voluntary nature of the relationship between two individuals in which the mentor functions as the trusted friend who listens, guides and enables through skilful questioning (Chao et al., 1992; Klasen \& Clutterbuck, 2002; Kram, 1983; Ragins \& Cotton, 1999). Ragins, Cotton and Miller (2000) also find that the quality of the mentoring relationship has a greater impact on mentees' work and career attitudes than the type of relationship (formal or informal) or even the design of the mentoring programme. Mentees with high-quality, formal mentors have a more positive work and career attitude than mentees with marginal, informal mentors. In this regard then, getting the best from a mentoring programme involves building in the best features of both the formal and the informal approaches. A formal structure is essential because it provides meaning and direction for relationships and support where necessary. However, individual relationships will flourish best when allowed to operate as informally as possible. Successful formal relationships very frequently go on to become successful informal ones (Clutterbuck, 2001).

Clutterbuck (2001) notes that the absence of structure, measurement and control that characterises the informal mentoring relationship also makes it difficult for the company to exert any influence on the nature and quality of the mentoring relationship. Discussions with informal mentoring pairs who had experience of both formal and informal mentoring indicated that the key is to create an environment where effective mentoring can flourish. Such an environment would contain some elements of structure, in the form of support available, but require no third party intervention in pairings.

In conclusion, this study suggests that particularly informal mentoring is regarded as a valuable career development and personal growth mechanism. The quality of the mentoring relationship appears to be influenced particularly by the frequency of interaction between the mentor and mentee, the characteristics of the mentor and the structure and direction provided by the mentor. As a result of the sampling strategy the findings of the study are limited to the respondents in the sample and cannot therefore be applied to all gender and race groups involved in mentoring relationships. More qualitative research with a broader representation of all gender and race groups is required to better illuminate mentors' and mentees' experiences of the mentoring relationship. Quantitative research (for example culture/climate surveys) could be launched to measure the magnitude of the key perceptions of mentors and mentees. The present study only looked at the recent experiences of mentors and mentees in one company. Ongoing and, in particular, longitudinal studies across various industries could make a valuable contribution to the body of knowledge concerned with mentoring relationships in the diverse South African organisational context.

\section{REFERENCES}

Allen, T.D., McManus, S.E. \& Russell, J.E.A. (1999). Newcomer socialization and stress: Formal peer relationships as a source of support. Journal of Vocational Behaviour, 54, 453-470.

Allen, T.D., Poteet, M.L. \& Burroughs, S.M. (1997). The mentor's perspective: A qualitative inquiry and future research agenda. Journal of Vocational Behavior, 51, 70-89.

Ashforth, B.E. \& Mael, F. (1989). Social identity theory and the organisation. Academy of Management Review, 14, 20-39.

Aryee, S. \& Debrah, Y.A. (1993). A cross-cultural application of a career planning model. Journal of Organisational Behavior, 14, 119-127.

Athey, S., Avery, C. \& Zemsky, P. (2000). Mentoring and diversity. American Economic Review, 90, 765-786.

Baruch, Y. (1999). Integrated career systems for the 2000s. International Journal of Manpower, 20 (7), 432-457.

Baruch, Y. (2001). Employability-substitute to loyalty. Human Resource Development International, 4 (4), 543-566.

Baruch, Y. (2002). Career systems in transition: A normative model for organisational career practices. Personnel Review, 32 (2), 231-251.

Baruch, Y. (2004). Transforming careers: From linear to multidirectional career paths: Organisational and individual perspectives. Career Development International, 9 (1), 58-73.

Baruch, Y. \& Rosenstein, E. (1992). Career planning and managing in high tech organisations. International Journal of Human Resource Management, 3 (3), 477-496.

Bogdan, R. \& Biklen, S.K. (1998). Qualitative research for education: An introduction to theory and methods. Boston: Allyn \& Bacon.

Chao, G.T., Walz, P.M. \& Gardner, P.D. (1992). Formal and informal mentorships: A comparison on mentoring functions and contrast with nonmentored counterparts. Personnel Psychology, 45, 619-636.

Clutterbuck, D. (2001). Everyone needs a mentor: Fostering talent at work. London: CIPD.

Clutterbuck, D. (2002). Building and sustaining the diversitymentoring relationship. In D. Clutterbuck \& B.R. Ragins (Eds.), Mentoring and diversity: An international perspective, 87-113. Oxford: Butterworth-Heinemann. 
Clutterbuck, D. \& Ragins, B.R. (2002). Mentoring and diversity: An international perspective. Johannesburg: ButterworthHeinemann.

Clutterbuck, D. \& Sweeney, J. (2003). Coaching and mentoring. Burnham: Clutterbuck.

Creswell, J.W. (1994). Research design: Qualitative and quantitative approaches. California: Sage.

Daloz, L.A. (1999). Mentor: Guiding the journey of adult learners (2nd ed.). San Francisco: Jossey-Bass.

Dreher, G.F. (1997). Substitutes for career mentoring: Promoting equal opportunity through career management and assessment systems. Journal of Vocational Behavior, 51, 110-124.

Ensher, E.A. \& Murphy, S.E. (1997). Effects of race, gender, perceived similarity, and contact on mentor relationships. Journal of Vocational Behavior, 50, 460-481.

Fagenson-Eland, E.A., Marks, M.A. \& Amendola, K.L. (1997) Perceptions of mentoring relationships. Journal of Vocational Behavior, 51, 29-42.

Finkelstein, L.M., Allen, T.D. \& Rhoton, L.A. (2003). An examination of the role of age in mentoring relationships. Group \& Organisation Management, 28 (2), 249-281.

Furnham, A. (2000). Work in 2020: Prognostications about the world of work 20 years into the millennium. Journal of Managerial Psychology, 15 (3), 242-254.

Greenhaus, J.H, Callanan, G.A. \& Godshalk, V.M. (2001). Career management. New York: Dryden Grobler, P.A., Warnich, S., Carrell, M.R., Elbert, N.F. \& Hatfield, R.D. (2002). Human resource management in South Africa. Canada: Thomson.

Hall, D.T. \& Mirvis, P.H. (1995). The new career contract: Developing the whole person at midlife and beyond. Journal of Vocational Behavior, 47, 269-289.

Hay, J. (1995). Transformational mentoring. New York: McGrawHill.

Huysamen, G.K. (1994). Methodology for the social and behavioural sciences. Halfway House: Southern.

Klasen, N. \& Clutterbuck, D. (2002). Implementing mentoring schemes: A practical guide to successful programs. London: Butterworth-Heinemann.

Kogler-Hill, S. \& Bahniuk, M.H. (1998). Promoting career success through mentoring. Review of Business, 19, 4-7.

Kram, K.E. (1983). Phases of the mentoring relationship. Academy of Management Journal, 26, 608-625.

Kram, K.E. (1996). A relational approach to career development. In D.T. Hall (Ed.), The career is dead: Long live the career (pp. 132-157). San Francisco: Jossey-Bass.

Kram, K.E. \& Hall, D.T. (1989). Mentoring as an antidote to stress during trauma. Human Resource Management, 28 (4), 493-510.
Kram, K.E. \& Hall, D.T. (1996). Mentoring in a context of diversity and turbulence. In S. Lobel \& E. Kossek (Eds.), Human resource strategies for managing diversity (pp. 108-136). London: Blackwell.

Linehan, M. \& Walsh, J.S. (1999). Mentoring relationships and the female managerial career. Career Development International, 4 (7), 348-352.

Megginson, D. \& Clutterbuck, D. (1995). Mentoring in action: A practical guide for managers. Oxford: Kogan Page.

Merriam, S.B. (2002). Qualitative research in practice: Examples for discussion and analysis. San Francisco, CA: Jossey-Bass.

Mirvis, P.H. \& Hall, D.T. (1994). Psychological success and the boundary-less career. Journal of Organisational Behavior, 15, 365-380.

Noe, R.A. (1988). An investigation of the determinants of successful assigned mentoring relationships. Personnel Psychology, 41, 457-479.

Ragins, B.R. (2002). Understanding diversified mentoring relationships: Definitions, challenges and strategies. In D. Clutterbuck \& B.R. Ragins (Eds.), Mentoring and diversity: An international perspective, 23-53. Oxford: ButterworthHeinemann.

Ragins, B.R., Cotton, J. \& Miller, J. (2000). Marginal mentoring: An examination of the effects of type of mentor and program design on work and career attitudes. Academy of Management Journal, 47, 1177-1194.

Ragins, B.R. \& McFarlin, D. (1990). Perception of mentor roles in cross-gender mentoring relationships. Journal of Vocational Behavior, 37, 321-339.

Schreuder, A.M.G. \& Theron, A.L. (2001). Careers: An organisational perspective. Cape Town: Juta.

Schuitema, E. (1998). Leadership: The Care and Growth Model. Cape Town: Ampersand Press.

Schurink, W.J. (2003). Qualitative research in management and organisational studies with reference to recent South African research. SA Journal of Human Resource Management, 1 (3), 2-14.

Siegel, P.H. \& Reinstein, A. (2001). An exploratory study of mentor relationships in large CPA firms. Scandinavian Journal of Management, 17, 421-436.

Strauss, A. \& Corbin, J. (1990). Basics of qualitative research: Grounded theory: Procedures and techniques. Newbury Park: Sage.

Tajfel, H. \& Turner, J.C. (1986). The social identity theory of intergroup counsellors. In S. Worchel \& W.G. Austin (Eds.), Psychology of intergroup relations, 7-24. London: Nelson-Hall. 